バイアスカット布の下垂形状の分析

$\begin{array}{cc}\text { 日本女子大学 } & \text { 大塚美智子 } \\ \text { 聖徳大学 } & \text { 三石幸夫 } \\ \text { 信州大学 } & \text { 清水義雄 }\end{array}$

\title{
Analysis of the Hanging Shape of the Bias Cut Cloth
}

\author{
Michiko Ohtsuka ${ }^{* 1}$, Yukio Mitsuishi ${ }^{* 2}$ and Yoshio Shimizu ${ }^{* 3}$ \\ *1 Japan Women's University, 2-8-1, Mejirodai, Bunkyouku, Tokyo112-8681, Japan \\ ${ }^{* 2}$ Seitoku University, 550, Iwase, Matsudo, Chiba271-8555, Japan \\ ${ }^{* 3}$ Shinshuu University,3-15-1,Tokida,Ueda,Nagano386-8567
}

\begin{abstract}
For the purpose of improving the accuracy of apparel product design or wearing simulation software, two kinds of Shingohsen $\mathrm{SG}_{1}$ and $\mathrm{SG}_{4}$, used in the previous report were employed to study the relationship among the material characteristics and the hanging shape, the extension in the bias direction, a thinning phenomenon and the like when sewn products were worn. 1 . The thinning ratio of each sample in the bias direction was high for $\mathrm{SG}_{4}$ at a low extension, but high for $\mathrm{SG}_{1}$ at a high extension. 2. Based on a change in the thinning ratio of a full circular skirt of $60 \mathrm{~cm}$ in length with time, the own weight of the full circular skirt was assumed to exert an influence close to that in a state of a highly extended sample cloth. 3. The widths were recovered in a part of 20 to $30 \mathrm{~cm}$ down from waistline in both $\mathrm{SG}_{1}$ and $\mathrm{SG}_{4}$. This is considered as a result of the cloth contacting the body in the part and measured values depending on the shape of the body. 4. The greatest problem of the simulation in both $\mathrm{SG}_{1}$ and $\mathrm{SG}_{4}$ was that the randomness of the hemline length was not expressed. The reason for this is thought to be the simulation without consideration for properties of thinning and extension depending on the own weight of the cloth or the contacting figure type.
\end{abstract}

(Received 30 April, 2003; Accepted 25 December, 2003)

\section{1. 緒 言}

素材の力学的性質は衣服の造形性や機能性を大きく左 右するものであり, とりわけ布のバイアス方向の持つ変形 しやすい性質は, 衣服の型崩れの大きな要因であると同時 に, 高い自由度を持つ性質として注目に值する[1.2.3].し かし, 現在これらの情報は極めて少ない. 特に, バイアス カットの衣服は左右対称のパターンを用いて作製しても, 時間経過に伴い, ヘムラインに明らかな歪みが発生する. たとえば, たて糸が右上がりのバイアスとたて糸が左上が りのバイアスとでは歪みの度合いが異なり, 非対称な形態 的物性を示す. 我々は既報[3]で, 従来は左右対称な形態的 物性をもつと考えられている織物の形態的, 力学的物性の 非対称性に着目し, 織物の保形性や縫製機能性に大きく関 係すると考えられる左右バイアス方向の物理的挙動の相 違について検討し，この原因として織組織，織糸の撚方向
や撚数, 太さが左右差を引き起こす大きな要因と考えられ ると報告した。このバイアス方向の形状の現れかたの実際 を実物製品で検証することは, 製品設計のみならず，着装 3 Dシミュレーションソフトの精度を高める上でも重要 な意味を持つ. そこで本研究では, 前報[2]で用いた新合繊 素材の中から、最も代表的なタイプ、織糸が極細瀻維から なり、膨らみ感があり、たて糸は撚りが少なく、よこ糸は 強然糸を用いたタイプー第 1 分類グループーの中から 2 種 の新合繊素材を選択適用して, その実際と原理を検証し, 素材特性と縫製品の着装時の下垂形状とバイアス方向の 伸び, 瘦せとの関連を明確にし、アパレル設計や着装シミ ユレーションの精度を高めるための一つの試みとして検 討を行った。 
試料は新合繊素材 2 種, ポリエステル $100 \%, \mathrm{SG}_{1}, \mathrm{SG}$ ${ }_{4}$, を用いた. 表 1 に各試料布の諸元を示す. $\mathrm{SG}_{1}$ は帝人 株製のアジェンティで, 最も代表的な膨らみ感のある織 糸からなるニューシルキーに属する. $\mathrm{SG}_{4}$ は同じく帝人㑣) 製のシルドールレジェルテ®で, 表面に産毛をもつサンド シルク調のピーチスキンである. 試料の特性については, 走查型電子顕微鏡による表面写真, 引張り強伸度, 摩擦係 数, 剛軟度, ドレープ性, 而摩耗性を測定した. 試料片の 瘦せ量は幅 $50 \mathrm{~mm}$ の試料を試長 $100 \mathrm{~mm}$ にして, テンシ ロン引張試験機に装着し，5.0，7.5，10.0，15.0\%伸長時 の試料片の中央部幅を測定し，原試料の幅に対する\%によ り求めた. 応力緩和, 弾性回復率は幅方向の減少 (瘦せ量) と同様の試料を用い, $2.5,5.0,10.0,15.0 \mathrm{~N}$ の応力を示す 伸長度まで伸長し, 1 分間放置までの応力緩和を測定し, その後直ちに応力を 0 になるまでもどし，その瞬間の弾性 回復率を求めた. 表面摩擦係数は最も一般的な傾斜板法で
測定、折り目摩擦はユニバーサル型摩擦試験機、エメリー ペーパー使用で破壞までの摩擦回数で求めた。縫製品の保 形性については, スカート丈 $60 \mathrm{~cm}$ の全円サーキュラスカ 一トを製作し， 7 号サイズのヌードボディに着装させ，下 垂時の形状および, バイアス方向の伸びと瘦せについて時 間経過に伴う変化量を測定した。

さらに着装 $3 \mathrm{D}$ シミュレーションソフトを用いて, 全円 サーキュラスカートのようなドレープの多い衣服をシミ ユレーションさせるためにはどのような物性データが必 須となるのかを究明するために, 新合繊素材の $S G_{1}, S$ $\mathrm{G}_{4}$ の 2 種の素材についてK E S で測定した物性值を入力 し，一般に使用されている $3 \mathrm{D}$ ソフト(i-Designer)を用い て三角メッシュの計算回数を 10 万回に設定し, 実験的に 全円サーキュラスカートを $3 \mathrm{D}$ でシミュレーションして 非接触 3 次元デジタイザシステムによる実物スカートの 3 D形状と比較検討した.

Table 1 Fundamental data of sample fabrics.

\begin{tabular}{ccccccc}
\hline $\begin{array}{c}\text { Sample } \\
\text { fabric }\end{array}$ & Component fiber & Weaves & $\begin{array}{c}\text { Thickness } \\
(\mathrm{mm})\end{array}$ & $\begin{array}{c}\text { Density of yarn } \\
(\text { warp*weft }) \\
(\mathrm{n} / \mathrm{cm})\end{array}$ & $\begin{array}{c}\text { Weight } \\
\left(\mathrm{g} / \mathrm{m}^{2}\right)\end{array}$ & Remarks \\
\hline $\mathrm{SG}_{1}$ & Polyester $100 \%$ & Plain & 0.33 & $62 * 28$ & 164.6 & Shingohsen material \\
\hline $\mathrm{SG}_{4}$ & Polyester $100 \%$ & Plain & 0.21 & $77 * 39$ & 94.0 & Shingohsen material \\
\hline
\end{tabular}

\section{3. 結果および考察}

\section{1 素材特性}

図 1 は各試料の表面の走査型電子顕微鏡 (S E M) 写真 である. $\mathrm{SG}_{1}$,アジェンティ ${ }^{\circledR}$ アたて糸があまい $\mathrm{Z}$ 撚り，よ こ糸は $\mathrm{S}$ 撚りで, 撚数が大で, たて糸の出入りが大きい構 造である. $\mathrm{SG}_{4}$, シルドール・レジェルテ ${ }^{\circledR}$ はたて糸は極め て甘い $\mathrm{S}$ 撚りで太く, よこ糸は強撚糸の $\mathrm{Z}$ 撚りで, 細く, たて糸, よこ糸の太さの差が顕著である.

表 2 には両素材の基本物性を示す. $\mathrm{SG}_{1}$ は重量が大で, 摩擦係数の小な素材であり, $\mathrm{SG}_{4}$ は, 重量が小で, 摩擦係 数が $\mathrm{SG}_{1}$ より大であり, その他は類似している. ここで摩 擦係数の warp $\times$ warp などは織物同士のたて方向とたて 方向をスライドさせた場合などの摩擦係数を示す。

上記の基本物性をもつ試料の力学的特性としての瘦せ の現象, 応力緩和, および弾性回復率の引張り試験機によ る定量的測定結果を以下に示す. 表 3 には各試料の所定伸
長度における瘦せ率を示した。 また，図 2 には表 3 の中よ り、特に伸長に対して瘦せの大きい各試料の所定伸長度に おけるバイアス方向の瘦せ率を示した. バイアス方向 $5 \%$ の伸長度では $\mathrm{SG}_{4}$ の瘦せ率が大であるが，10\%以上では $\mathrm{SG}_{1}$ の瘦せ率が大である. 図 3 は各試料の弾性回復率で, これは所定荷重(応力) まで伸長し， $1 \mathrm{~min}$ 応力緩和後の 瞬間の弾性回復率を示したものであるが, 弾性回復率はた て方向の低荷重時は $\mathrm{SG}_{4}$ の方が大であり, よこ方向, バイ アス方向は $\mathrm{SG}_{1}$ の方が大である.図 4 は各試料を所定荷重 まで伸長し， $1 \mathrm{~min}$ 後の応力緩和を初期応力を 100 とし, その\%で示したものである。図 3,4 より明らかなように、 各荷重負荷時の伸長における応力緩和と弾性回復の関係 は、応力緩和の大きいものは弾性回復率が小であることが わかる。ただたて方向の低荷重伸長時の応力緩和を除き、 よこ方向とバイアス方向において $\mathrm{SG}_{4}$ の応力緩和が $\mathrm{SG}_{1}$ より大であったが, $\mathrm{SG}_{1}$ は, 高荷重時に応力緩和が $\mathrm{SG}_{4}$ 近づく傾向を示した. 


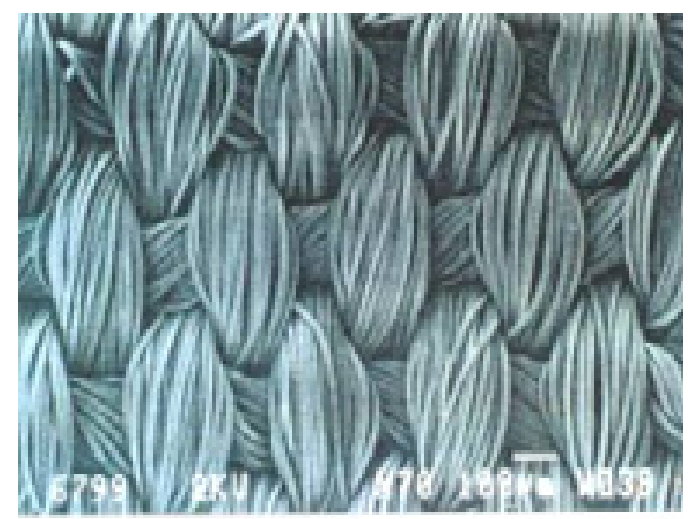

(a) SG1

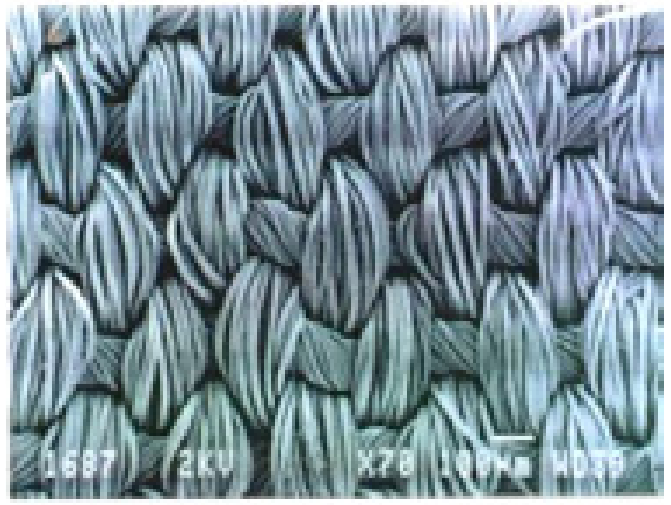

(b) SG4

Fig. 1 Scanning electron microscope photographs of sample fabrics.(a,b)

Table 2 Fundamental properties of sample fabrics.

\begin{tabular}{|c|c|c|c|c|c|c|c|c|c|c|c|c|}
\hline \multirow{2}{*}{$\begin{array}{l}\text { Sample } \\
\text { fabric }\end{array}$} & \multicolumn{2}{|c|}{ Warp } & \multicolumn{2}{|c|}{ Weft } & \multicolumn{3}{|c|}{ Coefficient of surface friction } & \multicolumn{2}{|c|}{ Frexibility* } & \multirow{2}{*}{$\begin{array}{c}\text { Drapability } \\
\text { (Drape } \\
\text { coefficient) }\end{array}$} & \multicolumn{2}{|c|}{ Fold abrasion } \\
\hline & $\begin{array}{l}\text { Strength } \\
(\mathrm{N} / 25 \mathrm{~mm})\end{array}$ & $\begin{array}{c}\text { Elongation } \\
(\%)\end{array}$ & $\begin{array}{l}\text { Strength } \\
(\mathrm{N} / 25 \mathrm{~mm})\end{array}$ & $\begin{array}{c}\text { Elongation } \\
(\%)\end{array}$ & warp $\times$ warp & warp $\times$ weft & weft $\times$ weft & $\begin{array}{l}\text { warp } \\
(\mathrm{m}\end{array}$ & weft & & $\begin{array}{l}\text { warp } \\
\text { (tir }\end{array}$ & weft \\
\hline $\mathrm{SG}_{1}$ & 30.8 & 48.5 & 20.7 & 46.0 & 0.5 & 0.5 & 1.9 & 32 & 29 & 0.237 & 85 & 92 \\
\hline $\mathrm{SG}_{4}$ & 29.7 & 33.2 & 17.0 & 34.7 & 1.8 & 2.0 & 2.3 & 30 & 23 & 0.223 & 70 & 115 \\
\hline
\end{tabular}

Table 3 Thinning percentage of width of sample fabrics.

\begin{tabular}{ccccc}
\hline Sample & $\begin{array}{c}\text { Elongation } \\
(\%)\end{array}$ & \multicolumn{3}{c}{ Thinning percentage of width } \\
& & warp & waft & Bias \\
\hline \multirow{4}{*}{ SG $_{1}$} & 5.0 & 98.7 & 99.8 & 90.1 \\
& 7.5 & 97.1 & 99.0 & 85.3 \\
& 10.0 & 96.4 & 99.4 & 79.7 \\
& 15.0 & 95.7 & 98.9 & 71.2 \\
\hline \multirow{3}{*}{$\mathrm{SG}_{4}$} & 5.0 & 97.2 & 97.6 & 88.4 \\
& 7.5 & 97.1 & 94.4 & 85.3 \\
& 10.0 & 98.3 & 94.6 & 81.7 \\
& 15.0 & 98.0 & 91.7 & 75.9 \\
\hline
\end{tabular}

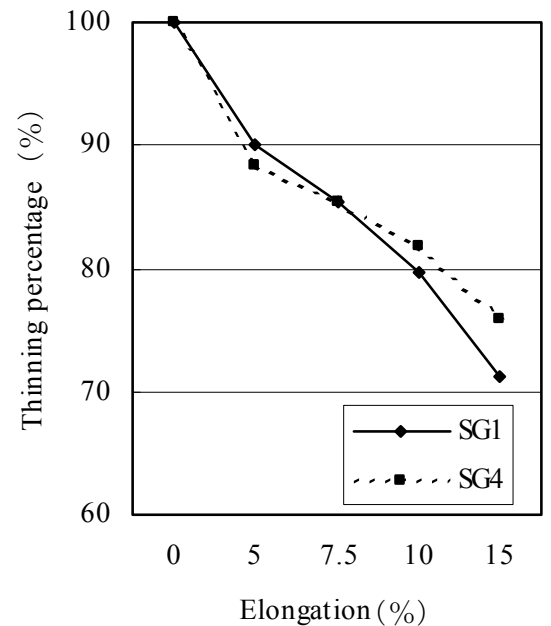

Fig. 2 Effect of elongation on thinning percentage of width of sample fabrics in bias directions. 

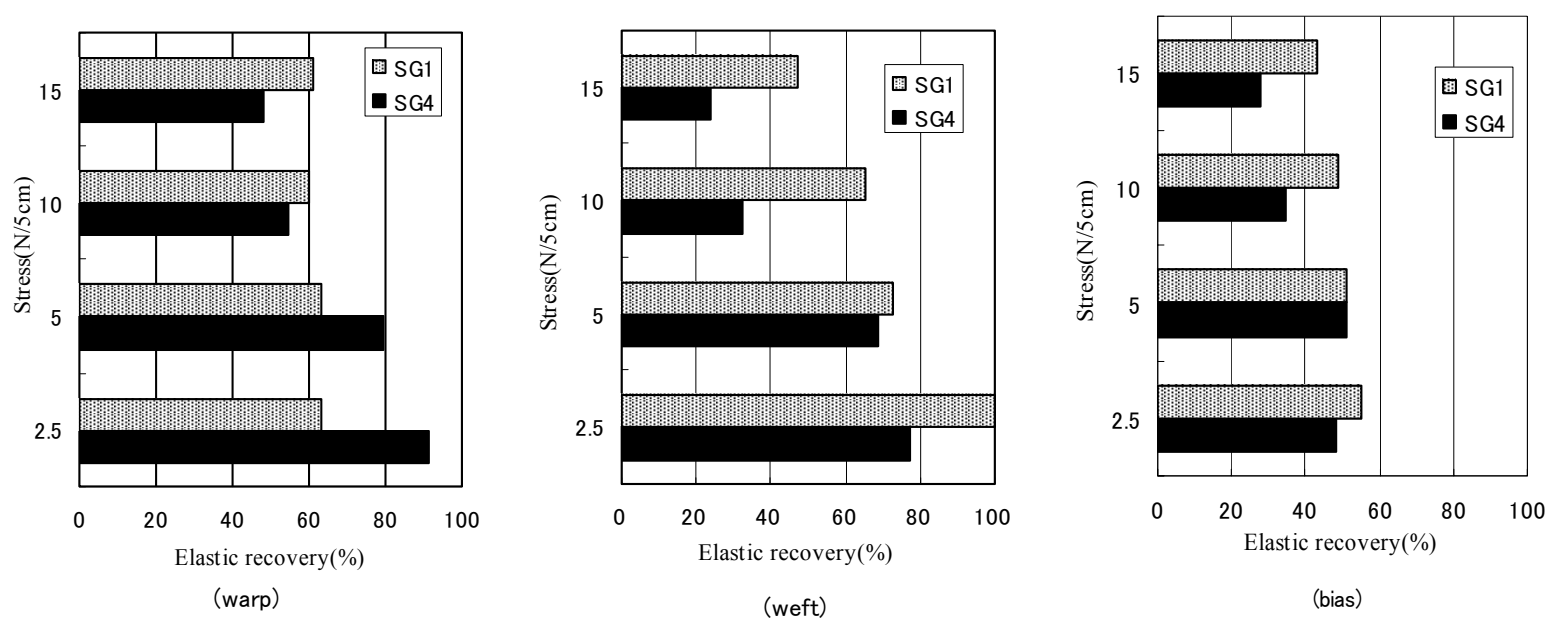

Fig. 3 Elastic recoveries of sample fabrics.
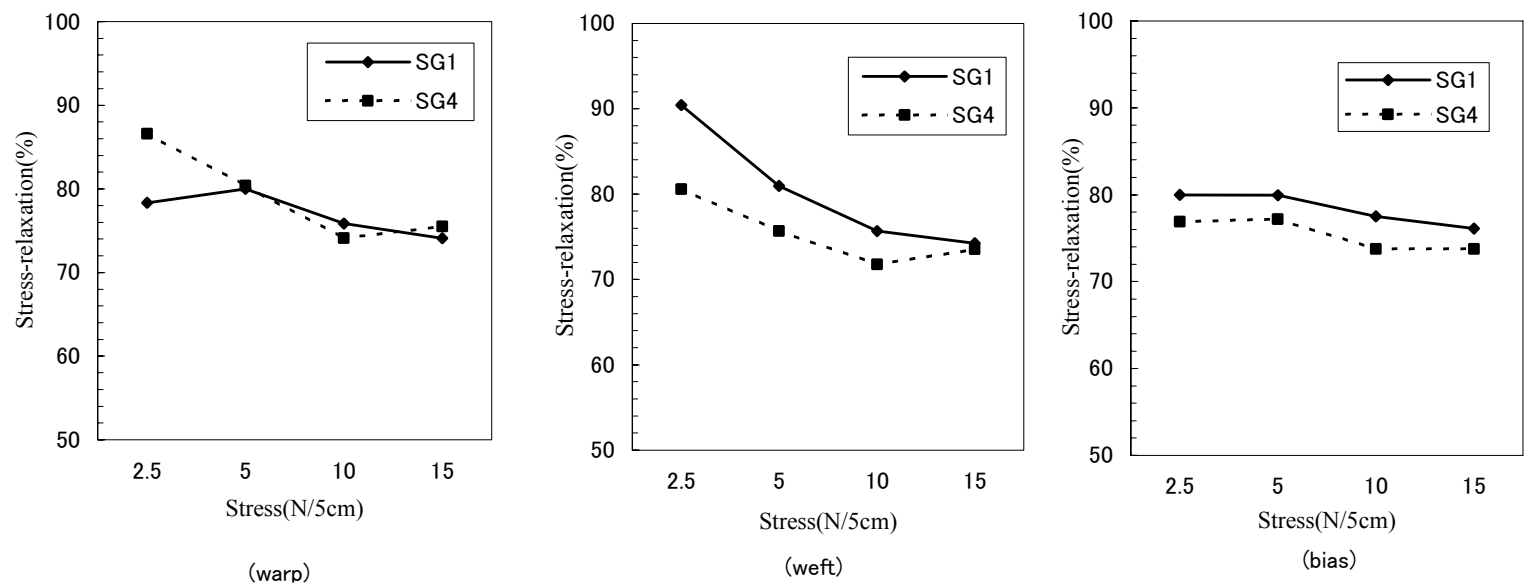

Fig. 4 Stress-relaxation of sample fabrics in the warp direction.

\section{2 全円サーキュラスカート下垂形状の経時変化}

実際に $\mathrm{SG}_{1}, \mathrm{SG}_{4}$ を用いてスカート丈 $60 \mathrm{~cm}$ の全円サー キュラスカートを作製し，ボディに着装させ，伸びと瘦せ の経時変化, フレア形状についての検討を行った. 縫製し た全円サーキュラスカートの保形性を見るために, ボディ に着装させ, 着装直後から 6 週間後までの伸びとやせの状 態を測定した.

サーキュラスカートの伸びと瘦せの測定方法は, 図 5 に 示す通り, 各試料のたて, よこ, バイアス方向に $10 \mathrm{~cm}$ ピ ッチに目盛りをつけ，伸びについては，バイアス方向にお ける $10 \mathrm{~cm}$ マーク間の長さを実測し, その值を伸び量とし, 瘦せについては, たて〜バイアスのマーク間の $\overline{\mathrm{A}} \mathrm{A}^{\mathrm{B}} \mathrm{B}$ を計 測し, 余弦, 正弦定理により水平方向の幅 $\mathrm{A} " \mathrm{~B}$ を求め, 瘦せ量とし, A B に対するA"B の比を瘦せ率とした. 図 6 に半径 $60 \mathrm{~cm}$ の全円サーキュラスカートの, ウエストより 10 20cm 間の伸び量の経時変化を示した. $\mathrm{SG}_{4}$ は下垂直 後に, $\mathrm{SG}_{1}$ は下垂 1 週間後までに大きく伸び, その後 4 , 6 週間と経過しても, やや伸びが増す程度で顕著な経時変 化は認められない，すなわち $2 \sim 3$ 週間で伸びの状態は安
定するものと考えられる. 図 7 には, 全円サーキュラスカ 一トのウエストより $20 \mathrm{~cm}$ 位置の瘦せ率の経時変化を示し た. 両サンプルとも下垂直後の瘦せ量は大であるが, 以後 の変化は少なく, 6 週間後, $\mathrm{SG}_{1}$ が $\mathrm{SG}_{4}$ より瘦せる傾向を 示す.これは $\mathrm{SG}_{1}$ の自重の大きさと高荷重時に $\mathrm{SG}_{1}$ の応 力緩和が大になるという結果に起因するものと考えられ るが，このことは，試料布の実験において，高伸長時に $\mathrm{SG}_{1}$ が $\mathrm{SG}_{4}$ より瘦せることに一致し, またこの結果から, サーキュラスカートの自重は試料布を高伸長した状態に 近い影響を与える事が推定できる. 図 8 には $\mathrm{SG}_{1}$ と $\mathrm{SG}_{4}$ のサーキュラスカートの伸びと瘦せの状態を二元グラフ に示した. サーキュラスカートの CB ラインはたて方向, $\mathrm{CA}$ ラインはバイアス方向を示す。伸びは $\mathrm{SG}_{4}$ の方が大で あるが,瘦せに拈ける両者の差はほとんど認められない.ま た, $\mathrm{SG}_{1}, \mathrm{SG}_{4}$ のいずれもウエストラインから $20 \sim 30 \mathrm{~cm}$ 間で幅が回復している様相がみられ，この間はボディのウ エスト〜ヒップ間スロープの部位であり, ボディのウエス トからボトム下端までの長さ $35 \mathrm{~cm}$ 間は布がボディに接触 している箇所であるといえる. すなわちこの部位における 


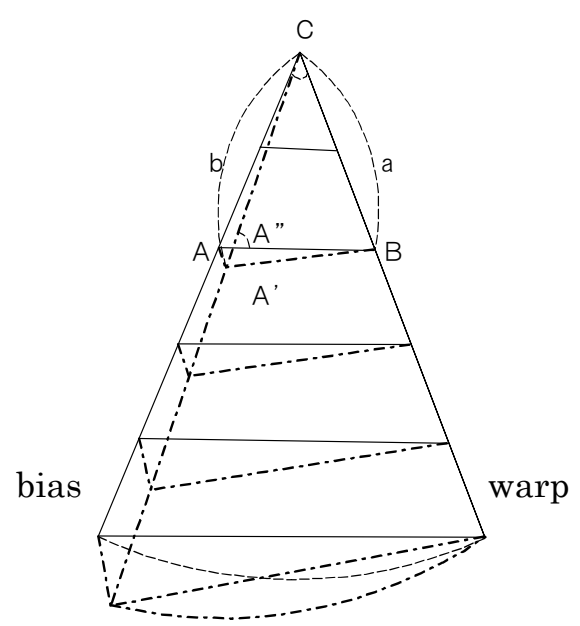

From the next two formulas,

$\overline{A^{\prime} \mathrm{B}}=\mathrm{a}^{2}+\mathrm{b}^{2}-2 \mathrm{abcos} \mathrm{C}$, and $\overline{\mathrm{A}} \overline{\mathrm{B}} / \sin \mathrm{C}=\mathrm{a} / \sin \mathrm{A} "$, $\overline{\mathrm{A}} \overline{\mathrm{B}}$ is calculated. $\overline{\mathrm{A}} \overline{\mathrm{B}} \mathrm{B}$ is a thinning value, and thinning ratio is described $\overline{\mathrm{A}}$ "B $/ \overline{\mathrm{AB}}$.

Fig. 5 The method of measurement of extension and thinning of a full circular skirt.
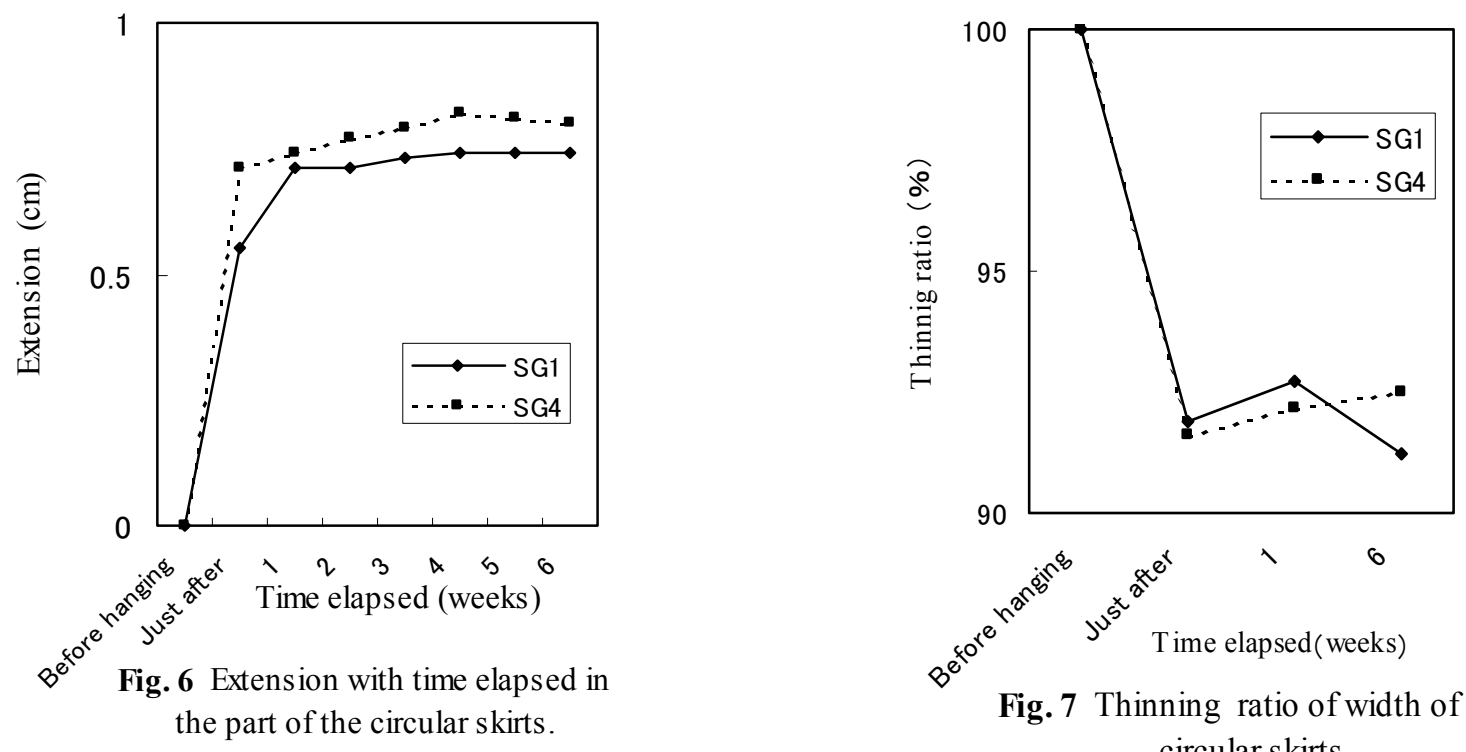

Fig. 7 Thinning ratio of width of the circular skirts.
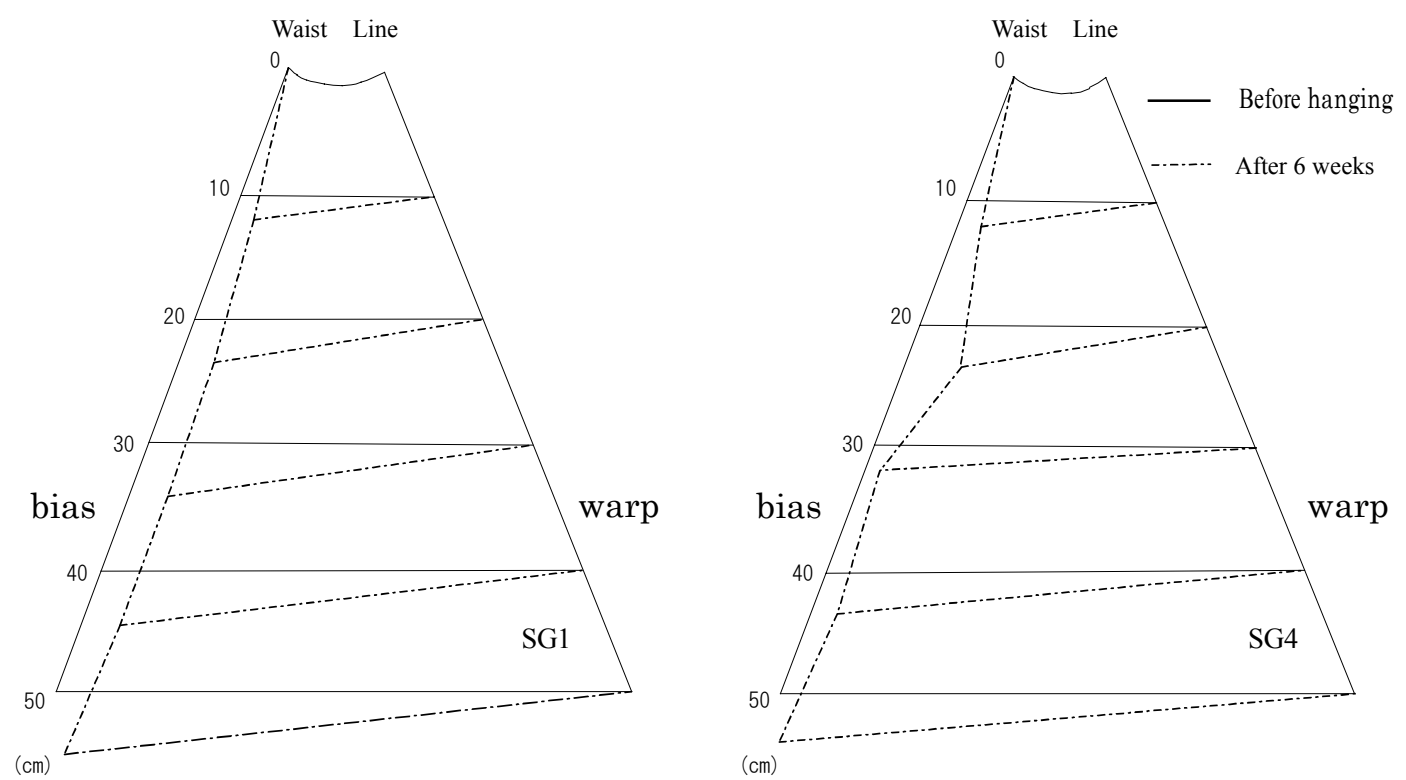

Fig. 8 Two dimensional graphs of extension and thinning of the full circular skirts. 
サーキュラスカートの測定値は体型に依存した值であり， 摩擦係数にも関係している部位であると考えられる。

\section{$3.33 D$ シミュレーションによる衣服形状の検討}

以上のような性質をもつバイアスカットの衣服を, 風合 評価の指標として用いられている KES の值でどこまでシ ミュレーションでき，またシミュレーションのために，ど のような情報が不足しているかを究明するため, 着装 $3 \mathrm{D}$ シミュレーションソフト（i - Designer）を用いて検討を 行った.

$\mathrm{SG}_{1}, \mathrm{SG}_{4}$ について表 4 の KES で測定した物性值を入 力し, $3 \mathrm{D}$ シミュレーションを行い, 実物スカートの形状 と比較検討した. シミュレーションに用いた物性值は, た て方向, よこ方向の引っ張り特性（伸び歪, EMT), せん 断特性（せん断剛さ，G），曲げ特性（曲げ剛性，B），お よび,厚さ,重量である.

実物スカートと同様のウエスト $60 \mathrm{~cm}$, スカート丈が $60 \mathrm{~cm}$ の四分円サーキュラスカートパターンを用い, 実物 のスカートとシミュレーションしたスカートの形状の相 違から検証した. シミュレーションの設定は, まず, 着装 シミュレーションソフトで型紙を読み込み, 地の目を前中 心と後ろ中心にたて地がくるように設定した. 次ぎに 7 号 サイズのボディを読み込み，ウエストを $60 \mathrm{~cm}$ に設定し， 着装シミュレーションを実行した。 3 角メッシュの計算回 数は 100,000 回とした.

図 9 に, 比較として非接触 3 次元デジタイザシステム

（Minolta VIVID900）により撮影した $\mathrm{SG}_{4}$ の実物スカー トの 3D 映像を示す.これと図 10 のシミュレーションし たスカートのドレープ形状とノード数を比較すると, 実物 スカートのドレープ形状は比較的垂直に垂れ下がる前面 に多くのドレープが出現し, 後面はヒップラインまでは体 型に沿いヒップラインからほぼ垂直に下垂している. 一方, シミュレーションでは前面と後面のドレープ形状が類似 しており，ヒップラインから下垂せず，ウエストから一律
にボディから離れる形で下垂しており, 前後のボディ形状 の相違がほとんど反映されない結果となった．またへムラ インはスカートの場合, バイアス方向に顕著な伸びが認め られ，ランダムな形状を示すが，シミュレーションでは丈 がほぼ一律となっている.ノード数は実物が 16 に対しシ ミュレーションは 10 と硬い印象を与えるものであった.

このように今回用いた着装 3Dシミュレーションソフト では伸びの性質, 体型を反映したドレープの表情が, シミ ユレーションできなかった. $\mathrm{SG}_{1}, \mathrm{SG}_{4}$ に共通する実物とシ ミュレーションとの最も大きな相違点は, スカートの伸び にともなうへムラインの垂直方向のランダム性が表現さ れていないという点であった.これは布の自重や体型に依 存する瘦せや伸びの変化量を考慮していないためと考え られる. また，表現の緻密さに関係する三角メッシュの設 定を 100,000 回と緻密に設定したが, シミュレーションま での計算時間が数時間かかり, 実用化にはいっそうの改善 が求められる. また, シミュレーション結果全体にいえる 事は布地が実際より硬く見えることで, これはシミュレー ションソフトに素材特性として KES の值のみを用いてい る事が問題であると考えられる. KES の值は布の初期的 物性, 小変形な実験室的な值であり, 実際製品のような大 きな長さや，面積を持った生地が，自重を伴い様々な形態 の人体に着装される場合の, 部位部位にかかる自重の影響 を考慮した值ではない，そのため，へムよりウエストに近 い部分が伸びることやヒップの突出と布の接触状態によ り垂れ下がりの状態が異なってくること, すなわち布のバ イアス方向の, 伸びの性質は全く考慮されていないため, ドレープの表情にリアリティーがでないものと思われる. 着装イメージを確認するための有用なソフトは開発され つつあり, 評価も高まっているが, 3D シミュレーション がサンプル縫製に替わるという本来の目的として機能す るためには，布のバイアス方向の伸びや瘦せ，衣服形状の 体型依存度などを測定し, これらのデータを蓄積して行く 必要がある。

Table 4 Data measured by KES.

\begin{tabular}{ccccccc}
\hline \multirow{2}{*}{$\begin{array}{c}\text { Sample } \\
\text { fabrics }\end{array}$} & Direction & $\begin{array}{c}\text { Tensile } \\
\text { property }\end{array}$ & $\begin{array}{c}\text { Shearing } \\
\text { property }\end{array}$ & $\begin{array}{c}\text { Bending } \\
\text { property }\end{array}$ & $\begin{array}{c}\text { Thickness } \\
(\mathrm{cm})\end{array}$ & $\begin{array}{c}\text { Weight } \\
\left(\mathrm{g} / \mathrm{cm}^{2}\right)\end{array}$ \\
\cline { 3 - 6 } & & $\begin{array}{c}\mathrm{EMT} \\
(\%)\end{array}$ & $\begin{array}{c}\mathrm{G} \\
(\mathrm{N} / \mathrm{cm} \cdot \mathrm{deg})\end{array}$ & $\begin{array}{c}\mathrm{B} \\
\left(\mathrm{Ncm}^{2} / \mathrm{cm}\right)\end{array}$ & & \\
\hline \multirow{2}{*}{$\mathrm{SG}_{1}$} & Warp & 6.54 & $0.225 \times 10^{-2}$ & $0.413 \times 10^{-2}$ & & \\
& Weft & 3.17 & $0.274 \times 10^{-2}$ & $0.020 \times 10^{-2}$ & 0.033 & 0.0165 \\
\hline \multirow{2}{*}{$\mathrm{SG}_{4}$} & Warp & 7.03 & $0.254 \times 10^{-2}$ & $0.019 \times 10^{-2}$ & & \\
& Weft & 9.25 & $0.210 \times 10^{-2}$ & $0.010 \times 10^{-2}$ & 0.021 & 0.0094 \\
\hline
\end{tabular}




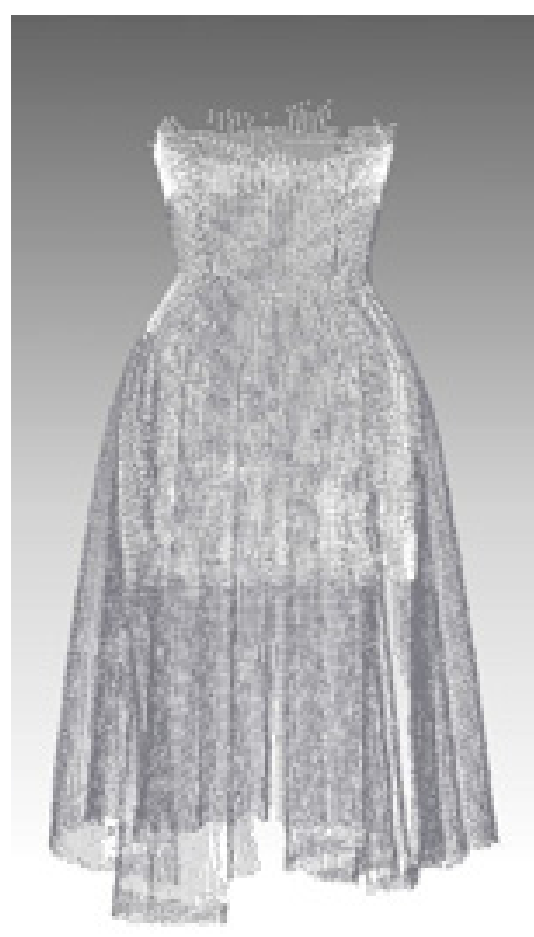

(a) Front form

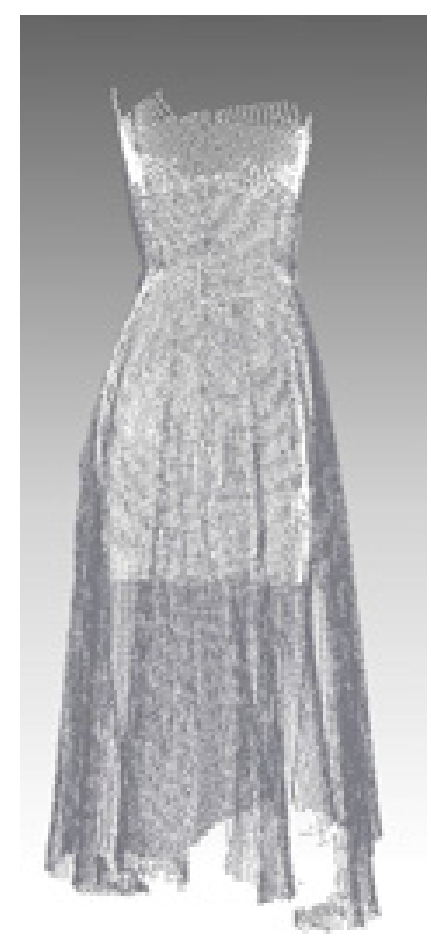

(b) Side form

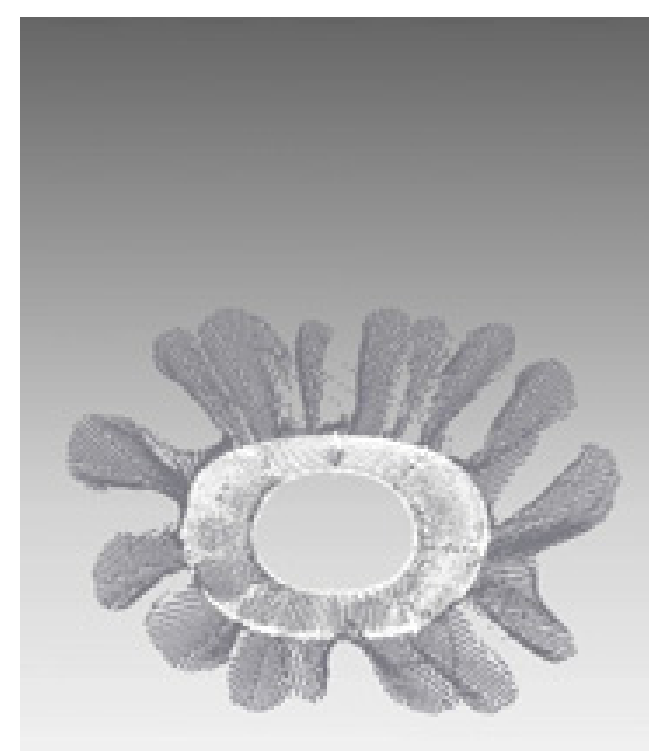

(c) Hem line form

Fig. 9 Non contact 3D simulation photographs of the full circular skirt. (SG 4)

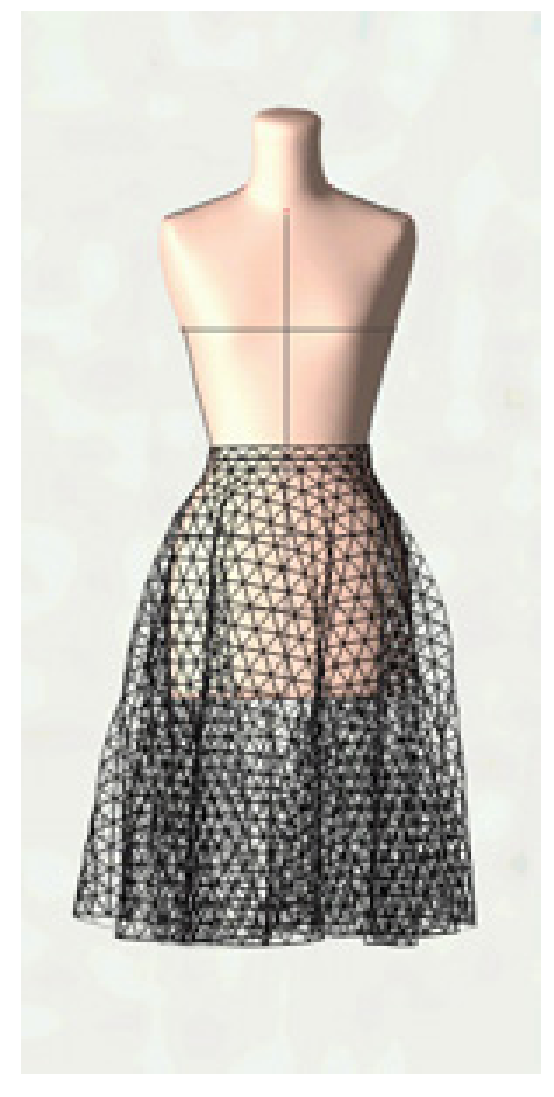

(a) Front form

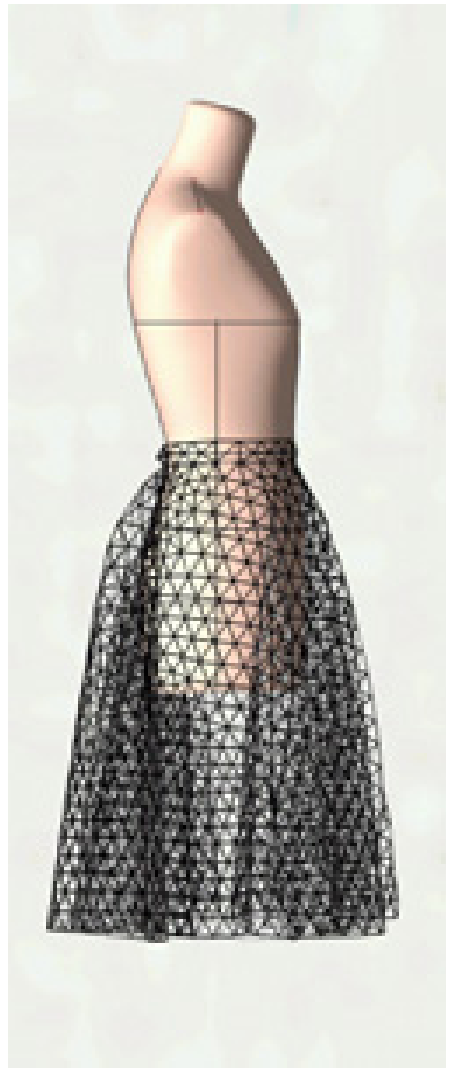

(b) Side form

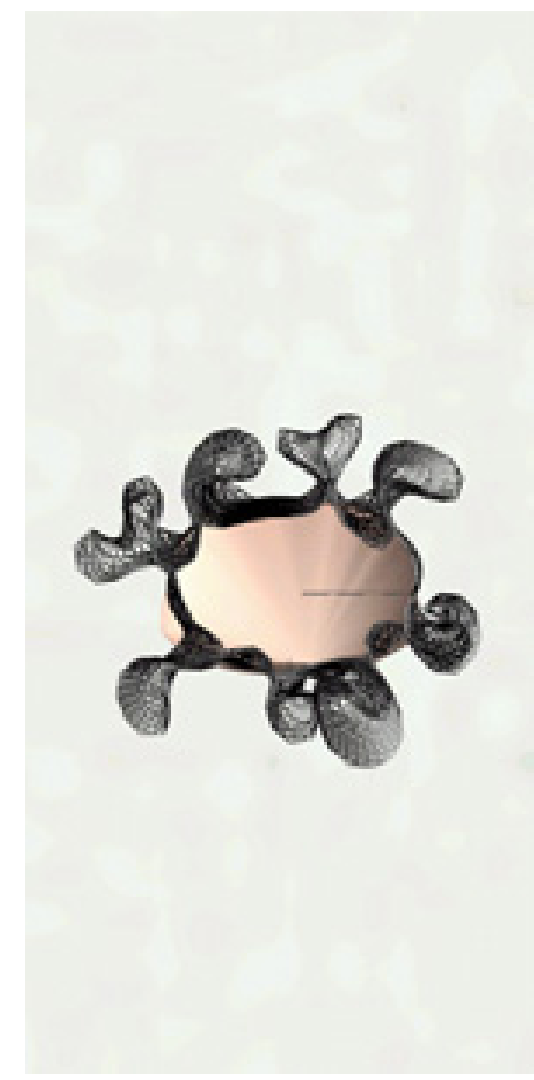

(c) Hem line form

Fig. 10 3D simulation of the circular skirt. (SG4) 


\section{4. 総 括}

代表的新合繊素材の素材特性を捉え，素材特性とその縫 製品の着装時の下垂形状, 伸び, 瘦せの現象などとの関連、 更に実物と着装シミュレーションとの相違に焦点を当て 検討した.

1. 2 種の新合繊素材, $\mathrm{SG}_{1}, \mathrm{SG}_{4}$ 試料の所定伸長度にお けるバイアス方向の瘦せの状態において, 低伸長では $\mathrm{SG}_{4}$ の瘦せ率が大であったが, 高伸長では $\mathrm{SG}_{1}$ の瘦せ 率が大であった。

2. 全円サーキュラスカートの瘦せ率の経時変化から, 全 円サーキュラスカートの自重は試料布を高伸長した 状態に近い影響を与える事が推定された。

3. $\mathrm{SG}_{1}, \mathrm{SG}_{4}$ のいずれもにおいてもウエストラインから 20〜30 c m間で幅が回復したが, この間はボディに布 が接触しているため, ボディの形状に依存し, 影響さ れた測定值であるためと考えられる.
4. $\mathrm{SG}_{1}, \mathrm{SG}_{4}$ に共通する実物とシミュレーションとの最 も大きな相違点は, スカートの伸びにともなうへムラ インの垂直方向のランダム性が表現されていないと いう点であった。これは布の自重や体型に依存する瘦 せや伸びの性質を考慮していないためと考えられる.

\section{付 記}

本報をまとめるにあたり，実験にご協力いただいた，三 谷優子さんに感謝いたします。

\section{文 献}

1. M.Matsudaira, J,Text, Machinery, 50, 242 (1997).

2. M.Ohtsuka,Y.Mitsuishi, Sen'i Gakkaishi,59, 173-180 (2003).

3. M.Ohtsuka,Y.Mitsuishi, Sen'i Gakkaishi,53, 512-516(1997) 